\title{
COVID-19: Normalleşme sürecinde alerji kliniği
}

\author{
Kurtuluş $\operatorname{AKSU}^{1}$ (ID)
}

\author{
${ }^{1}$ Sağlık Bilimleri Üniversitesi, Ankara Atatürk Göğüs Hastalıkları ve \\ Göğüs Cerrahisi Eğitim ve Araştırma Hastanesi, Göğüs Hastalıkları Kliniği, \\ Ankara, Türkiye \\ ${ }^{1}$ Department of Chest Diseases, Health Sciences University, Ankara Atatürk \\ Chest Diseases and Chest Surgery Training and Research Hospital, \\ Ankara, Turkey
}

Makale atıfi: Aksu K. COVID-19: Normalleşme sürecinde alerji kliniği. Tuberk Toraks 2020;68(2):200-204.

\section{Yazışma Adresi (Address for Correspondence)}

\section{Dr. Kurtuluş AKSU}

Ankara Atatürk Sanatoryumu Hastanesi, Keçiören, 06290

ANKARA - TÜRKIYE

e-mail: kurtulusaksu@yahoo.com

OTelif Hakkı 2020 Tüberküloz ve Toraks. Makale metnine www.tuberktoraks.org web adresinden ulaşılabilir.
Yaşadığımız günlerde tüm dünyada koronavirüs hastalığı (COVID19) ile mücadele ediliyor olmasına karşın halen bu infeksiyonun yönetimi ile ilgili birçok temel noktada netlik yoktur. "Severe acute respiratory syndrome coronavirus 2 (SARS-CoV-2)" virüsünün neden olduğu COVID-19 Türkiye'nin gündemine 11 Mart 2020'de ilk olgunun tespit edilmesiyle birlikte ciddi olarak girmiş̧ir. Takip eden günlerde hızlı bir karar mekanizmasıyla 16 Mart 2020'de eğitime ara verilmiş, 20 Mart 2020'de tüm özel ve vakıf hastaneleri pandemi hastanesi ilan edilmiş̧ir. 21 Mart 2020'de 65 yaş üzeri ve kronik rahatsızlığı olan vatandaşlar için sokağa çıkma kısıtlaması getirilmiş ve ayrıca 68 ülkeyle uçuşlar durdurulmuştur. 3 Nisan 2020 tarihine gelindiğinde 20 yaş altı gençler ve çocuklar için sokağa çıkma kısıtlamasıyla birlikte 31 ile giriş çıkışlar durdurulmuştur. 10 Nisan 2020'den itibaren ise hafta sonları ve resmi/ bayram tatillerinde sokağa çıkma kısıtlaması büyük bir titizlik ile uygulanmışıır. Haziran 2020 itibariyle de normalleşme sürecine geçilmiştir. Bu süreçte en önemli husus virüsün bulaşma yolunun bilinmesi ve buna yönelik önlemlerin alınarak hem biz hizmet veren konumunda olan sağlık çalışanlarının korunması hem de bireysel korunmanın sağlanarak virüsun toplum içindeki hızlı yayılımının önlenerek sağlık hizmetlerinin kapasitesinin aşılmaması olacaktır. Ancak virüsün tam olarak bulaş mekanizması bilinmezliğini korumaktadır. 09.07.2020 tarihi itibariyle pubmed arama motorunda 'covid-19 and transmission' diye arama yapıldığında 3750 sonuca ulaşılmaktadır. Bu veri de bu konuda hala bir belirsizliğin olup araştırmaların devam ettiğinin göstergesi olarak düşünülebilir. Nature dergisinde 2 Nisan 2020 tarihinde yayınlanan bir makalede COVID-19 bulaşma yolu ile ilgili olarak uzman- 
ların net bir fikir birliğine varamadıkları açık bir şekilde belirtilmiştir (1). Mayıs 2020'de yayınlanan bir yazıda ise solunum damlacıklarının dağılımı konusunda; öksürük ile büyük çaplı damlacıklar (100-1000 $\mu \mathrm{m}$ çapında) ve küçük damlacıklar (1-10 $\mu \mathrm{m})$, konuşma sırasında sadece küçük damlacıkların ortama dağıldığı gösterilmiştir. Yine solunum damlacıklarının yere düşme süresi ile ilgili olarak görünür büyük damlalar (500 $\mu \mathrm{m}$ çaplı) 1 saniye içinde yere düşerken, $5 \mu \mathrm{m}$ çaplı küçük damlacıkların $160 \mathrm{~cm}$ yükseklikte üretildiğinde yere düşmesinin 9 dakika olduğu gösterilmiştir. Bu çalışmada ayrıca öksürükten sonra oluşan küçük damlacıklar havada ne kadar süzülür sorusuna yanıt aranmış ve havalandırma olmayan bir ortamda 5 dakika, yanlızca mekanik havalandırma olduğunda 1.4 dakika, kapı ve pencere ile desteklenen mekanik havalandırma olduğunda ise damlacık sayısının yarıya inmesi 30 saniye olarak bulunmuştur (2). Bu verilerin sonucunda yazarlar; kötü havalandırılan alanlarda küçük solunum damlacıklarının devam etmesi SARSCoV-2'nin yayılmasına katkıda bulunabilir, küçük damlacıkların aerosoller ile iletimi sadece yüksek performanslı yüz maskeleri kullanılarak önlenebilir ve en önemlisi ağıı otoritelerinin yetersiz havalandırılan kamusal alanlardan mümkün olduğunca kaçınma önerisi dikkate alınmalıdır yorumunu yapmışlardır (2). İyi havalandırmanın sağlanması dışında hastanelere ve/veya diğer kamusal alanlara girişte kişilerin vücut ısısını ölçmek bizlere yardımcı olabilir mi? COVID-19 hastalığının klinik bulgularına bakıldığında hastaların büyük çoğunluğunda ateş olduğu, ateş ile birlikte öksürük ve halsizlik ya da kas ağrısı olduğu, daha az sıklıkta ise balgam, baş ağrısı ve ishal görüldüğü bilinmektedir. Hastaların yaklaşık yarısında ise nefes darlığı gelişmektedir (3). Dolayısıyla kamusal alanlara girişte vücut ısısı ölçümü yapmak oldukça mantıklı bir yaklaşım olmakla birlikte bizleri tam olarak korumayacaktır. Hatta alerji klinikleri özelinde COVID-19 hastalığı semptomatolojisine bakıldığında semptomların hastalığın erken aşamalarda alerjik rinit ile örtüştüğü, ilerleyen dönemde ise daha net tanımlanmış COVID19 semptomlarına ilerlediği dolayısıyla allerji kliniğine başvuran hastalarla örtüşen semptomatoloji nedeniyle riskin göz ardı edilemez olduğu aşikardır. Hatta COVID-19 hastalığında tanımlanmış cilt lezyonların olması bu riski daha da artırmaktadır. Çünkü ürtiker gibi hastalıklar alerji kliniğinin önemli bir hasta grubunu oluşturmaktadır (4). Bizleri korkutan asıl sorun ise öksüren, burnu akan ve hapşıran ama ateşi olamayan kişilerin alerji ön tanısıyla alerji polikliniklerine başvurması ve bu semptomların aslında çok rahatılıkla
COVID-19 hastalığının semptomları olabileceği gerçeğidir.

Alerji Kliniklerinde değerlendirilen belli başlı patolojiler astım, alerjik rinit, kronik öksürük, deri alerjileri (ürtiker, anjioödem, atopik dermatit, kontakt dermatit), ilaç alerjileri, besin alerjileri, arı alerjisi, lateks alerjisi ve anafilaksidir.

Astımlı hastalarda hizmet düzenlenmesi: Rinovirüs ve respiratuvar sinsityal virüs gibi solunum yolu virüsleri viral kaynaklı astım alevlenmelerinin bilinen en sık tetikleyicileridir. Fakat hem SARS hem COVID-19 hastalarında kronik solunum yolu hastalıklarının görülme sıklığı genel popülasyondaki görülme sıklığına göre daha azdır (5). Ancak kronik akciğer hastalığı olan kişilerin COVID-19 hastalığına yakalanmaları halinde kliniklerinin ağır ve mortal seyirli olma oranı daha yüksektir (6). Astım, SARS-CoV-2 enfeksiyonunun şiddeti için önemli bir risk faktörü olarak tanımlanmamışıır. SARS-CoV-2 ile ilgili olarak Wuhan'da COVID-19 pozitifliği doğrulanmış hastaneye yatırılan 140 hastanın hiçbirinin astım veya eşlik eden atopik hastalığının bulunmadığı bildirildi (7). Yine COVID-19 tanılı 548 hastada astım prevalansı (\%0.9) Wuhan'daki yetişkin popülasyondaki astım prevalansına (\%6.4) göre belirgin düşük bulunmuştur (8). Çocuk ve erişkinlerde yapılmış yakın zamanlı bir araştırmada astımı ve solunumsal allerjisi olan hastalarda hava yollarındaki ACE2 gen ekspresyonunun azalmış olduğu gösterilmiştir. Bu çalışmanın bulguları astım ve solunum yolu alerjisi olan hastalarda COVID-19 görülme sıklığının düşüklügünü potansiyel olarak açıklamaktadır (9). Astımlı hastaların inhale steroid kullanımının immün sistem yanıtlarını zayıflattığı yönünde endişe duymakta ve kullanmakta oldukları inhaler tedavilere devam etmekten çekinmektedirler (10). Klinisyenler de inhale kortikosteroid kullanmakta olan SARS-CoV-2 pozitif olguların tedavilerine devam etmeleri konusunda endişe duymaktadırlar (11). Bu endişelerin altında yatan neden ise koronavirüs ve diğer solunum yolu virüslerine bağlı akciğer tutulumu ve hasarı varlığında kortikosteroid tedavisi kullanımının akciğerlerden ve kandan virüs klirensini geciktirdiği, psikoz ve diyabet gibi sorunlara yol açtığı ve mortaliteyi artırdığının bilinmesidir (12). Steroid içeren inhaler tedaviler kullanıyor olmanın COVID-19 enfeksiyonu açısından zararlı veya yararlı olduğuna dair klinik veri yoktur. COVID-19 pandemisi esnasında astımlı hastalarda IKS tedavisinin kesilmesi gerektiği yönünde hiçbir kanıt yoktur. İnhale kortikosteroid (IKS) kullanımının özellikle koronavirüs olmak üzere viral enfeksiyonlarda 
yararlı olabileceğine dair kanıtlar bildirilmiştir. İn vitro olarak insan solunum yolu epitel hücrelerinin budesonid ile muamelesinin koronavirus (HCoV-229E) replikasyonunu ve sitokin üretimini baskıladığı gösterilmiştir. Yine siklesonidin de in vitro olarak SARSCoV-2 RNA replikasyonunu ve hücre hasarını baskıladığı gösterilmiştir $(13,14)$. IKS kullanımı ile astımı kontrol altında olan hastalarda tedavileri aynı şekilde devam edilmelidir. Hastalar kontrol edici tedavilerine aksatmadan devam etmelidir. Hastaların özellikle IKS kullanımına ilişkin tereddütleri giderilmeli ve tedavilerini aksatacak olurlarsa astım kontrolünün bozulabileceği ve astım alevlenmesi yaşayabilecekleri açıklanmalıdır (15). Özellikle kontrolsüz astım alevlenmeye yol açarak acil başvurularını, hastane yatışlarını, yoğun bakım yatışlarını ve astıma bağlı ölümleri artırması olasıdır. En iyi şekilde kontrol edilen astım, enfeksiyonla mücadelede ilk silahtır. İstediğimiz son şey hastalarımızın astım ilaçlarını bırakması ve alevlenme ile acil/hastanelere başvurması olacaktır. Ağır astım tanısı olan ve astım kontrolünün ancak düşük doz oral kortikosteroid tedavisi ile sağlanabildiği hastalarda kortikosteroid tedavisinin kesilmesi astım alevlenmelerine yol açabileceği için tedavi mümkün olan en düşük dozda devam edilmelidir (16). Yüksek riskli hastaların bakımına diğer gruplara göre öncelik verilmelidir. Astımı kötüleşen veya alevlenme bulguları olan hastalar için, COVID-19 enfeksiyonu riskleri belirlenerek planlama yapılır. COVID-19 şüphesi olan hiçbir hastanın alerji kliniğinde görülmemesi tavsiye edilir. Bunun yerine hasta astımı değerlendirmek ve yönetmek için personel ve ekipman donanımlı olan COVID-19 izolasyonu yapabilen başka bir tesiste görülmelidir (17). Astımlı hastaların rutin takibinde; iyi kontrollü astımı olan hastalarla yüz yüze rutin takip ziyaretlerini erteleyip bakımın sürekliliğini sağlamak için tele-sağlık da dahil olmak üzere bu hastalar için sanal bakım seçeneklerini düşünmek gerekmektedir. Son 3-6 ay içinde alevlenme için acil başvurusu ya da hastane yatışı, $\geq 2$ oral steroid kürü almış, kontrol edici tedavide basamak artırılmış olan hastaların takibine ise öncelik verilmelidir (17). Astımlı hastalarda klinik bozulma halindeki değerlendirmede ise ağır astım alevlenmesi riski ve COVID-19 riskine göre plan yapılmalıdır. Ağır astım alevlenmesi riski ve COVID-19 riski her ikisi de düşük ise tele-sağ lık, ağır astım alevlenmesi riski düşük ve COVID-19 riski yüksek ise aerosol oluşturucu işlem gerekebileceği için COVID-19 izolasyonu yapabilen başka bir merkezde hasta görülmelidir. Ağır astım alevlenmesi riski yüksek ve COVID-19 riski düşük ise klinikte yüz-yüze değer- lendirme yapılmalıdır. Ağır astım alevlenmesi riski yüksek ve COVID-19 riski de yüksek ise astımı değerlendirmek ve yönetmek için personel ve ekipman donanımlı olan COVID-19 izolasyonu yapabilen başka bir merkezde görülmelidir (17). Nebulizatörlerin sağlık bakım ortamlarında kullanımı özellikle SARSCoV-2'nin sağlık çalışanlarına yayılma riskini arttırmak açısından sakıncalıdır. Alevlenme tedavisinde hızlı etkili bronkodilatörlerin spacer yoluyla verilmesi tercih edilmelidir. Kullanılan ara parçalar üretici önerilerine göre sterilize edilmeli ya da, ideal olarak, her hasta için ayrı bir spacer kullanılmalıdır (15). Sonuç olarak $\mathrm{Bu}$ pandemi sürecinde tedavilerini düzenli kullanan astımlı hastaların COVID-19 ile ilişkili olarak daha ciddi sorunları ya da daha fazla hastaneye yatışları olduğuna dair herhangi bir veriye sahip değiliz. Astımlı bir bireyin COVID-19 dahil herhangi bir viral solunum yolu enfeksiyonunun komplikasyonlarından korunması için en önemli tedbir, astımında iyi kontrol sağlamaktır.

Biyolojik ajanlar için hizmet ayarlaması: Ağır astımlı olgularda biyolojik ajanlar (anti-IL5, anti-IL4/IL13, anti-lgE) ile tedaviye geçilerek sistemik kortikosteroid tedavisi kesilen olgular klinik pratikte giderek artmaktadır $(15,18)$. Astımlı hastalarda pandemi döneminde biyolojik tedaviler aynen devam edilmelidir. Astım tedavisi için kullanılan biyolojik ürünler konusunda hastalar bilgilendirilmelidir. Biyolojiklerin başlatılması evde bakım hizmetleriyle yapılmalıdır. Bu mümkün değilse tercihen en fazla 1-2 doz hastane vizitinde yapıldıktan sonra evde devam edilmelidir. İdame tedavisinde olan hastalar için de doz atlanması yerine kullanıma hazır enjektör ile ev uygulamasına geçilmesi uygundur $(19,20)$. Ülkemizde de biyolojikler ile tedavinin düzenli uygulamalarının mümkünse hastaneye gelmeden evde enjeksiyonuna olanak tanıyan yasal düzenlemeler yapılması faydalı olacaktır.

Alerjik rinitli hastalarda hizmet düzenlenmesi: Alerjik rinitli hastaların değerlendirilmesi ve yüz yüze takibi ertelenmeli veya tele-sağlık yöntemi ile devam ettirilmelidir. Pandemi yönetim ve izolasyon önlemleri sırasında alerjik rinit için hizmetin azaltılması şiddetle tavsiye edilmektedir. Bu çerçevede deri prick testi yapılması uygun değildir. Deri prick testleri ertelenmeli veya in vitro serum spesifik IgE testleri kullanılmalıdır. Ancak spesifik IgE çalışılması için de hastanın sağlık merkezine girmesi gerekeceği için bu uygulama da önerilmemektedir. En iyi yaklaşım anamneze dayalı olarak kaçınma önlemlerinin uygulanması ve gerekli hallerde uygun tedavilerin başlanmasıdır (17). 
İnhalan alerjen immünoterapi için hizmet ayarlaması: Alerjik rinitli hastalar için olağandışı bir durum olmadıkça immünoterapi başlanmamalıdır. Anafilaksi veya astıma bağlı hastaneye yatışına yol açan bir tetikleyiciye kaçınılmaz maruziyet varsa yapılmalıdır. Alerjik rinit için halihazırda inhalan alerjen immünoterapisi alan hastalar için program modifikasyonu yapılabilir. Başlangıç dönemindeki hastalar için 2 haftada bir uygulama, idame dönemi için 6 haftada bir uygulama şeklinde aralık genişletme yapılabilir. Astımla ilişkili sonuçlar için hastaneye yatışla sonuçlanan bir tetikleyiciye kaçınılmaz maruziyeti olan hastalar haricinde pandemik önlemler kaldırılana kadar tedavi askıya alma da bir seçenek olarak düşünülebilir (17).

\section{Venom immünoterapi (VIT) immünoterapi için hizmet} ayarlaması: Venom (arı zehiri) anafilaksisi öyküsü olan hastalarda VIT başlatılması veya idamesi için hizmette herhangi bir değişiklik olmamalıdır. Ancak idame döneminde olan hastalar, en az bir yıldır idame döneminde olmak şartıyla her 2 ayda bir aralıklarla uygulama yapılabilir. Anafilaksi öyküsü olmayıp, büyük lokal reaksiyon veya izole kutanöz sistemik reaksiyon öyküsü olan hastalar için VIT bu süreçte başlatılmamalı veya sürdürülmemelidir. VIT idamesi, daha önce sistemik bir reaksiyon yaşamamış, anafilaksi olması durumunda anafilaksiyi şiddetlendirebilecek veya tedavisini zorlaştıracak komorbiditeleri veya ilaç kullanımı olmayan hastalarda evde kendilerince uygulanabilir. Enjekte edilebilir epinefrin evde uygulama esnasında bulundurulmalıdır (17). Hastalar bu konuda çok iyi bilgilendirilmeli ve aydınlatılmış yazılı onamları mutlaka alınmalıdır.

Gıda alerjisi, ilaç alerjisi ve anafilaksi için hizmet ayarlaması: Belli durumlar (çocuklarda kritik beslenme problemine yol açan durumlar ve yer fıstığının duyarlılığına ilişkin şüpheler, ilaç alerjisi etiketinin kaldırılması, ilaç provokasyon testi veya ilaç duyarsızlaştırılması için acil veya kritik bir ihtiyacın olduğu ilaç alerjisi hastası, immün yetmezlikli kişilere aşı uygulanması öncesi provokasyon testi ihtiyacı) gıda ve ilaç provokasyon testleri ertelenmelidir (17).

Anjiyoödem için hizmet ayarlaması: Özellikle faringeal/laringeal, abdominal veya genital tutulumları olan şiddetli anjiyoödem vakaları yüz yüze ziyaretler veya tele-sağ Iık hizmeti için önceliklendirilmelidirler. Bu tür hastalar herediter anjiyoödem için laboratuvar çalışmasına ihtiyaç duyabilir. Son 6 ayda belirgin atak yaşamamış herediter anjiyoödem hastaların tele-sağlık ile takibi en uygun yöntemdir (17).
Kronik spontan ürtiker için hizmet ayarlaması: Kanıtlar laboratuvar testlerinin kronik spontan ürtikerli çoğu hastada ertelenebileceğini düşündürmektedir. Bu nedenle kronik ürtikerin değerlendirmesi için vizitler ertelenebilir. Potent nonsedatize antihistaminikler ile hastaya tedavi başlamak uygundur. Tele-sağlık değerlendirmelerinde antihistaminik tedaviye yanıtsız kronik spontan ürtikeri olan uygun seçilmiş hastalarda omalizumab başlanması da dahil olmak üzere daha fazla değerlendirme için yüz yüze ziyaret gerekebilir (17).

Atopik dermatit için hizmet ayarlaması: Hafif atopik dermatit değerlendirmesi için vizitler ertelenerek topikal kortikosteroidlerle tedavi verilebilir. Orta derecede atopik dermatit için tele-sağlık değerlendirme yapılabilir. Şiddetli hastalık varlığında yüz yüze ziyaretler gerekebilir ve atopik dermatiti olan diğer tüm hastalara göre öncelikli olmalıdır. Fark edilebilir bir olası gıda tetikleyicisi olmadan deri prick veya serolojik testler önerilmemektedir. Atopik dermatit için biyolojik tedavinin başlatılması uygulanabilir bir seçenek olmaya devam etmektedir. Çünkü evde uygulanabilir ve yüz yüze değerlendirme ihtiyacını düşürür. Hastalar endikasyon açısından dikkatli değerlendirilmelidir (17).

\section{Biz klinik olarak neler yaptık?}

Hastaneye girişlerde hastalara ateş kontrolü yapılarak maske takmaları sağlandı. Ziyaretçi girişleri kısıtlandı. Bekleme alanı koridorları ve koltuklarda düzenleme yapıldı. Yatan hasta odaları tek kişilik olarak düzenlendi. Hastanemizde solunum fonksiyon testleri ikinci bir düzenlemeye kadar durduruldu. Yalnızca gereklilik durumunda COVID-19 PCR testi negatif olan olgularda yapılmaya devam edildi. Cilt prick testi odasında aynı anda birkaç hastaya test yapılması yerine her seferde tek hasta alınmaya başlandı. ilaç provokasyon ve desensitizasyon odası koltuklarında sayı ve mesafe düzenlemesi yapıldı. Tüberküloz ilaç aşırı duyarlılı̆̆ı olan hastalara randevuları her güne tek randevu şeklinde düzenlendi. İmmünoterapi uygulamalarında doz aralıkları uzatıldı. Biyolojik ajan enjeksiyonlarına aynen devam edildi. Klinikte yapılan tüm testler hastanın poliklinikte değerlendirildiği gün yapılmaya çalışıldı. Test için ileri tarihe randevu verilmemeye çalışıldı. Böylelikle bu açıdan hasta test/uygulama odasına geçmeden önce potansiyel COVID-19 olasılığı açısından değerlendirilmiş oldu. Randevu verilecek olursa randevu günü hekim tarafından değerlendirilmesi sağlandı. îlaç provokasyon ve desensitizasyon işlemleri zorunluluk olmadığı sürece durduruldu. Akciğer kanseri hastalarında kemoterapi ve tüberküloz 
hastalarında anti-TB ilaç desensitizasyonları aksatılmadan devam edildi. Astım alevlenmesi tedavileri ve provokasyon işlemleri esnasında bronkodilatör kullanımı ihtiyacı doğması halinde aerosol tedavilerin nebulizatör yerine spacer ile uygulanması yönünde tercih geliştirildi.

Virüsün yayılmasını sınırlamak için tek strateji enfekte olmuş bireyleri ve enfeksiyon riski yüksek olanları tanımlamak ve karantinaya almaktır. Ancak vaktinde ve doğru sonuç veren test ne yazık ki şu aşamada mevcut değildir. Bu nedenle sağlık hizmeti sunucuları pandeminin kendi bölgelerindeki günlük değişimini izlemek ve yetkililerin, uzmanların tavsiyelerini uygulamaya hazır olmakla yükümlüdür. Pandemide durum hızla değişiyor ve hızlı, esnek ve bilgili bir karşılık gerektiriyor.

\section{KAYNAKLAR}

1. Lewis D. Is the coronavirus airborne? Experts can't agree. Nature 2020;580(7802):175.

2. Somsen GA, van Rijn C, Kooij S, Bem RA, Bonn D. Small droplet aerosols in poorly ventilated spaces and SARSCoV-2 transmission [published online ahead of print, 2020 May 27]. Lancet Respir Med 2020;8(7):658-659.

3. Huang C, Wang Y, Li X, et al. Clinical features of patients infected with 2019 novel coronavirus in Wuhan, China [published correction appears in Lancet. 2020 Jan 30;:]. Lancet 2020;395(10223):497-506.

4. Naziroğlu T, Sözen S, Özkan P, Şeker S, Aksu K. A case of COVID-19 pneumonia presenting with acute urticaria [published online ahead of print, 2020 May 13]. Dermatol Ther 2020;e13575. doi:10.1111/dth.13575.

5. Halpin DMG, Faner $R$, Sibila O, Badia JR, Agusti A. Do chronic respiratory diseases or their treatment affect the risk of SARS-CoV-2 infection?. Lancet Respir Med 2020;8(5):436-438.

6. Novel Coronavirus Pneumonia Emergency Response Epidemiology Team. Vital surveillances: the epidemiological characteristics of an outbreak of 2019 novel coronavirus diseases (COVID-19)-China, 2020. China CDC Weekly. http://weekly.chinacdc.cn/en/article/ doi/10.46234/ccdcw2020.032. Erişim tarihi: 17.05.2020.

7. Zhang J, Dong $X$, Cao $Y Y$, et al. Clinical characteristics of 140 patients infected with SARS-CoV-2 in Wuhan, China [published online ahead of print, 2020 Feb 19]. Allergy 2020;10.1111/all.14238.
8. Li X, Xu S, Yu M, et al. Risk factors for severity and mortality in adult COVID-19 inpatients in Wuhan. J Allergy Clin Immunol 2020;146(1):110-118.

9. Jackson DI, Busse WW, Bacharier LB, et al. Association of respiratory allergy, asthma, and expression of the SARSCoV-2 receptor ACE2. I Allergy Clin Immunol 2020;146(1):203-206.e3.

10. Asthma and Allergy Foundation of America- www.aafa.org (Erişim tarihi: 16.05.2020).

11. Halpin DMG, Singh D, Hadfield RM. Inhaled corticosteroids and COVID-19: a systematic review and clinical perspective. Eur Respir J. 2020;55(5):2001009. Published 2020 May 7. doi:10.1183/13993003.01009-2020.

12. Russell CD, Millar JE, Baillie JK. Clinical evidence does not support corticosteroid treatment for 2019-nCoV lung injury. Lancet 2020;395(10223):473-475.

13. Yamaya $M$, Nishimura $H$, Deng $X$, et al. Inhibitory effects of glycopyrronium, formoterol, and budesonide on coronavirus HCoV-229E replication and cytokine production by primary cultures of human nasal and tracheal epithelial cells. Respir Investig 2020;58(3):155-168.

14. Matsuyama S, Kawase $M$, Nao $N$, Shirato $K$, Ujike $M$, Kamitani W, Shimojima M, Fukushi S. The inhaled corticosteroid ciclesonide blocks coronavirus RNA replication by targeting viral NSP15. bioRxiv 2020.03.11.987016; doi: https://doi.org/10.1101/2020.03.11.987016.

15. Global Initiative for Asthma. Global Strategy for Asthma Management and Prevention, 2020. Available from: www.ginasthma.org (Erişim tarihi 29.06.2020).

16. https://www.medscape.com/viewarticle/927264\#vp_2 (Erişim tarihi: 17.05.2020)

17. Shaker MS, Oppenheimer J, Grayson M, et al. COVID-19: Pandemic Contingency Planning for the Allergy and Immunology Clinic. I Allergy Clin Immunol Pract 2020;8(5):1477-1488.e5.

18. https://asthma.ca/get-help/asthma-3/treatment/biologics/ (Erişim tarihi: 11.07.2020).

19. Lommatzsch M, Stoll P, Virchow JC. COVID-19 in a patient with severe asthma treated with Omalizumab [published online ahead of print, 2020 Jun 16]. Allergy 2020;10.1111/ all. 14456 .

20. Förster-Ruhrmann U, Szczepek AJ, Bachert C, Olze H. COVID-19 in a patient with severe chronic rhinosinusitis with nasal polyps during therapy with dupilumab. J Allergy Clin Immunol 2020;146(1):218-220.e2. 